\title{
Pemanfaatan Limbah Sayuran, Buah, dan Kotoran Hewan menjadi Pupuk Organik Cair (POC) di Kelompok Tani Rukun Makaryo, Mojogedang, Karanganyar
}

\section{Utilization of Vegetables, Fruits, and Animal Manure Waste into Liquid Organic Fertilizer (POC) at Rukun Makaryo Farmer Group, Mojogedang, Karanganyar}

\author{
Catur Rini Sulistyaningsih \\ Fakultas Pertanian, Universitas Veteran Bangun Nusantara, Sukoharjo, Indonesia \\ caturrinisulistyaningsih@gmail.com
}

Riwayat Artikel: Dikirim 4 Oktober 2020; Diterima 16 November 2020; Diterbitkan 30 November 2020

\begin{abstract}
Abstrak
Pengabdian kepada masyarakat ini bertujuan untuk mengurangi pencemaran limbah, khususnya limbah sayuran, buah dan kotoran hewan; serta meningkatan produksi POC untuk mencukupi kebutuhan pupuk pada lahan pertanian. Evaluasi indikator keberhasilan penyuluhan dan pelatihan mengindikasikan skor post-test meningkat $\geq 25 \%$ dari pada skor pre-test. Dari 15 partisipan yang dilibatkan dalam kedua tes, tidak ditemukan nilai peningkatan pemahaman yang di bawah $25 \%$, yang akhirnya indikator keberhasilan yang sudah dicapai dalam kegiatan ini sebanyak 100\% dan anggotanya yang mendapat skor 2 dan 3 berjumlah 15 orang, serta rerata peningkatannya sebanyak $42.46 \%$.
\end{abstract}

Kata kunci: Limbah Sayuran, Limbah Buah, Kotoran Hewan, POC.

\begin{abstract}
This Community Service is aimed at reducing waste pollution, especially vegetable, fruit and animal waste; and increasing POC production to meet fertilizer needs on agricultural land. The results of community service activities are evaluated on the success indicators of counseling and training if the post test score has increased $\geq 25 \%$ from the pre-test score. Out of 15 participants taking the post-test and pre-test, none of them had an increase in understanding value below 25\%, eventually the training and counseling activities reached 100\% success indicators and the training and service members reaching scores of 2 and 3 comprising 15 people, and the average of the increasing number comprised $42.46 \%$.
\end{abstract}

Keywords: Vegetable waste, fruit waste, animal waste, POC.

\section{PENDAHULUAN}

Jual beli sayuran merupakan kegiatan yang dilakukan masyakarat Indonesia di pasar tradisional. Kebanyakan sayuran yang sudah rusak hanya diletakkan atau ditinggalkan begitu saja di areal pinggir pasar yang akhirnya hal ini mengurangi keindahan lingkungan. Aroma yang menyengat hidung pun akhirnya tercium di mana-mana. Limbah buah-buahan adalah bahan buangan yang secara umum pembuangannya dilakukan dengan open dumping tanpa diolah lebih lanjut yang akhirnya hal ini membuat lingkungan terganggu dan aroma busuk pun dapat tercium. Gizi yang terkandung dalam limbah buah-buahan tergolong rendah, yakni serat kasar sebanyak 5-38\% dan protein kasar 115\% (Jalaluddin, 2016).

Berlebihnya buah-buahan yang beredar di masyarakat memicu volume sampah dari limbah buah menjadi tinggi. Sampai sekarang, penuntasan masalah limbah ini belum terlaksana secara maksimal sebab rasa sadar masyakarat masih tergolong minim dalam mengolah limbah. Limbah tersebut pun memunculkan pelbagai masalah, contohnya munculnya penyakit, polusi air dan udara, dll. Dalam keseharian, buah-buahan sangat esensial dalam kehidupan manusia. 
Biasanya, hanya daging buah yang dimanfaatkan sebagai salad, jus, selai, dan sirup. Pektin yang dihasilkan oleh kulit buah umumnya berkisar 10,40-16,76\% (Tang, et al., 2011). Limbah buah-buahan dapat dimanfaatkan sebagai pupuk cair organik sebab limbah tersebut telah mengandung Nitrogen (N), Fospor (P), Kalium (K), Vitamin, Kalsium (Ca), Zat Besi (Fe), Natrium (Na), Magnesium (Mg) dsb. Kandungan tersebut benar-benar bermanfaat bagi kesuburan tanah yang akhirnya dapat dipergunakan sebagai bahan pupuk organik cair (POC) ataupun mikroorganisme lokal (MOL) (Nur, 2019).

Melimpahnya limbah buah-buahan berpotensi tinggi untuk dimanfaatkan sebagai sumber bahan baku untuk membuat POC. Kesuburan tanah pun dapat dioptimalkan dengan kandungan yang terdapat pada limbah buah, yang akhirnya dapat dimanfaatkan sebagai MOL ataupun POC, yang dijelaskan sebagai pupuk yang megambil kemanfaatan dari organisme lokal. POC pun dapat digunakan sebagai opsi lain yang merupakan upaya dalam pembebasan tanaman dari efek buruk, yakni residu kimia yang biasanya masyakarat gunakan dalam penyuburan tanaman (Nisa, 2016). Maka dari itu, pengoptimalan dalam pemanfaatan limbah buah betul-betul harus dilakukan agar nilai tambahnya, termasuk aspek marketing-nya, dapat dinaikkan.

Sayuran yang tersisa dan tidak mempunyai kelayakan untuk dijual akan diberi harga yang tidak mahal saat hampir siang. Namun jika tidak ada orang yang membelinya, maka pedagang akan meninggalkannya di pasar yang akhirnya menjadi sampah. Buah dan sayuran berkategori sampah organik yang memunculkan aroma yang busuk dan membuat lingkungan tercemar. Sampah dan sayuran yang baunya menusuk hidung dapat dimanfaatkan sebagai pemasukan bagi para ibu rumah tangga. Masalah yang kelompok tani Sido Rukun hadapi di antaranya: (1) minimnya pendapatan, (2) sulitnya menyubstitusikan pupuk kimia menjadi organik, dan (3) terbatasnya fasilitas untuk memproduksi pupuk secara mandiri. COrganik yang tersimpan dalam limbah sayuran sebanyak $31,24 \%$ atau melebihi persentase tersebut jika dibanding COrganik yang terkandung pada limbah isi rumen. Di samping itu, kandungan kandungan N-Total yang ada pada limbah sayuran sebanyak $2,57 \%$ atau lebih tinggi daripada kandungan N-Total pada limbah isi rumen. Pendek kata, limbah sayuran bisa dimanfaatkan sebagai sumber tambahan COrganik, N-Total (Damayanti, 2017).

Limbah ternak ialah sisa buangan dari aktivitas usaha peternakan, contohnya pemeliharaan ternak, rumah potong hewan, pengolahan produk ternak, dll. Cakupan limbah ini yaitu limbah cair dan padat, misalnya urine, feses, kulit telur, isi rumen, sisa makanan, darah, kuku, bulu, dll (Sihombing, 2000). Tingkat hasil limbah akan semakin naik jika usaha peternakan semakin berkembang. Total hasil limbah peternakan bergantung pada tipe dan besarnya usaha, lantai kandang, termasuk spesies ternak.

Hasil limbah ternak yang paling banyak yaitu kotoran sapi yang berupa urine dan feces. Selain itu, yang menghasilkan banyak manure adalah ternak ruminansia, contohnya kambing, sapi, domba, dan kerbau. Lazimnya, setiap $\mathrm{kg}$ susu yang diproduksi ternak perah menghasilkan $2 \mathrm{~kg}$ feses, sementara setiap $\mathrm{kg}$ daging sapi menghasilkan $25 \mathrm{~kg}$ feses (Sihombing, 2000). Soehadji (1992) memaparkan, cakupan dari limbah pakan yaitu seluruh kotoran yang merupakan hasil dari aktivitas usaha peternakan yang diwujudkan dalam limbah cair, padat, gas, termasuk sisa pakan. Limbah padat ialah seluruh limbah yang bentuknya padat, contohnya kotoran ternak, isi perut dari ternak yang sudah dipotong, termasuk ternak yang sudah mati. Limbah cair mengacu pada limbah yang bentuknya cair, misalnya urine ataupun air dari hasil cuci peralatan. Sementara limbah gas ialah seluruh limbah yang bentuknya gas. 
Gas metan (CH4) yang mencemari lingkungan dapat memunculkan bau yang menyengat. Proses pencernaan ternak ruminansia menjadi pemicu munculnya CH4 di mana gas ini merupakan gas yang memicu terjadinya global warming dan rusaknya lapisan ozon dengan laju 1\% tiap tahunnya dan mengalami kenaikan secara kontinu. Terlebih lagi di Indonesia, emisi metan per unit pakan atau laju konversi metan terbilang sangat tinggi. Hal ini dikarenakan rendahnya mutu hijauan pakan yang diberikan. Metan yang dimunculkan akan semakin besar jika pakan yang kualitasnya rendah semakin banyak diberikan (Suryahadi dkk., 2002).

Limbah diinterpretasi sebagai bahan organik ataupun non organik yang pemanfaatannya sudah tidak dilanjutkan lagi, yang akhirnya hal ini memunculkan masalah krusial pada lingkungan jika penanganannya tidak diterapkan seoptimal mungkin. Limbah bermula dari pelbagai sumber hasil buangan dari proses produksi, misalnya limbah peternakan. Limbah ini dapat berasal dari olahan produksi ternak, rumah potong hewan, termasuk kegiatan usaha ternak.

Limbah ternak mempunyai nilai ekonomi yang begitu besar jika terdapat ketepatan dalam pengolahannya. Terdapat sejumlah cara yang bisa diimplentasikan agar limbah tersebut dapat terolah dengan maksimal. Contohnya yaitu dengan cara mengolah kotoran menjadi pupuk kandang, yakni melalui pengeringan kotoran ternak. Teknik yang tergolong simpel ini pun sudah kerap dijumpai. Kendati demikian, teknik pengolahan tersebut belum berkategori ramah lingkungan sebab pengeringan kotoran ternak pastinya akan membuat lingkungan tercemar yang berupa aroma yang menusuk hidung sehingga hal ini akan memicu terganggunya pernafasan dan kesehatan.

Dalam limbah ternak, nutrisi dan zat padat masih terkandung di dalamnya dan tentunya berpotensi memicu adanya kehidupan jasad renik yang akhirnya membuat lingkungan tercemar. Sebuah studi yang berkenaan dengan tercemarnya air yang dikarenakan adanya limbah ternak mengindikasikan bahwa pada total sapi dengan berat badan $5.000 \mathrm{~kg}$, dalam satu hari manure yang diproduksinya bisa mencemari 9.084 x $107 \mathrm{~m} 3$ air.

Di samping itu, limbah ternak kerap menbuat lingkungan tercemar secara biologis, yakni sebagai medium bagi lalat untuk pembiakan. Air yang terkandung pada manure berada di kisaran $27 \%$ s.d. $86 \%$ dan menjadi media yang paling sempurna bagi tumbuh kembang larva lalat. Sementara kandungan air manure 65-85\% menjadi media yang paling optimum bagi lalat untuk bertelur. Limbah ternak yang keadaannya sudah mengering juga bisa mencemari lingkungan, yakni diwujudkan dalam debu. Pencemaran udara yang tertinggi di areal penggemukan sapi yaitu sekitar pukul 18.00, di mana kandungan debunya melebihi 6000 $\mathrm{mg} / \mathrm{m} 3$, yang mengindikasikan terlampauinya batas ambang yang bisa ditoleransi untuk kesegaran udara di lingkungan $(3000 \mathrm{mg} / \mathrm{m} 3)$.

Dampak dari air yang tercemar karena limbah ternak ruminansia yaitu naiknya kadar $\mathrm{N}$, di mana senyawa ini berstatus sebagai polutan yang memiliki efek polusi tersendiri dan kemunculannya bisa memicu risiko menurunnya mutu perairan sebagai dampak dari proses eutrofikasi, termasuk menurunnya konsentrasi oksigen terlarut yang merupakan hasil proses nitrifikasi yang ada dalam air dan bisa memunculkan gangguan pada biota air (Farida, 1978). POC ialah pupuk yang mempunyai kandungan bahan kimia yang tergolong sedikit (maksimal 5\%), berperan dalam pemberian hara yang dibutuhkan tanaman pada tanah dikarenakan bentuknya yang cair. Oleh sebab itu, apabila kapasitas pupuk pada tanah tergolong eksesif, maka absorpsi komposisi pupuk yang diperlukan dapat diatur oleh tanaman secara otomatis tanpa adanya hambatan. POC dalam pemupukan tentunya lebih mempunyai pemerataan; konsentrasi pupuk di satu tempat tidak akan 
menumpuk karena terlarutnya pupuk tersebut sudah $100 \%$. Keistimewaan pupuk ini yaitu defisiensi hara bisa diatasi dengan pupuk tersebut dalam waktu singkat, pupuk pun tidak memunculkan masalah dalam pencucian hara, serta berkemampuan dalam penyediaan hara dalam waktu singkat (Musnamar 2006).

Permasalahan ini tentunya harus mendapatkan penanganan dan penyelesaian. Ada sejumlah hal yang bisa dilaksanakan di kelompok tani ini dalam upaya penanggulangan limbah ternak yakni dengan dibuatnya starter-mol berbasis rumen ternak yang difungsikan juga sebagai pupuk hayati dan dibuatnya pupuk organik padat berbasis feses ternak dan sisa pakan ternak sapi yang ditambahkan dengan sekam (limbah padi).

\section{Kondisi Sumber Daya Manusia Mitra}

Kelompok Tani Rukun Makaryo didirikan pada tanggal 17 Juni 1999, di mana jumlah anggotanya yaitu 42 orang, dan ketuanya bernama Paiman Hadi Supadmo. Latar belakang pendidikan anggotanya tergolong variatif, yakni mencakup lulusan SD (25 orang), SMP (10 orang), SMA/SMK (4 orang) dan sarjana (3 orang) dengan umur reratanya yaitu di atas 30 tahun. Kelompok tani ini memiliki visi dan misi kelompok. Visi Kelompok yaitu "Kemandirian petani di bidang usaha demi mewujudkan kesejahteraan bersama" sementara misinya yaitu "Meningkatkan sumber daya petani, membentuk jaringan antar petani, membuka dan menciptakan lapangan pekerjaan, merintis pasar, meningkatkan hasil produksi baik secara kualitas dan secara kuantitas."

\section{Kondisi Aspek Produksi dan Manajemen Mitra "Kelompok Tani Rukun Makaryo"}

Tanaman padi yang diusahakan oleh petani anggota kelompok tani Rukun Makaryo ditanam di lahan sewa dan lahan milik mereka sendiri. Teknologi produksi yang dimiliki mereka yaitu mesin perontok malai, mesin pembersih bulir, dan traktor.
Lahannya diolah dengan traktor dan tanahnya yang sudah terolah dibiarkan selama sepekan, lalu dilakukan penggaruan selama satu pekan lagi, dan dilanjutkan dengan pemerataan. Benih padi yang mereka gunakan di antaranya mentik, IR 64, padi merah dan padi hitam. Mereka pun melakukan pertanian organik murni dengan penggunaan pupuk organik sejak awal penanaman. Aliran air sungai dimanfaatkan dalam pengairannya, namun mereka memakai mesin pompa air saat musim kemarau. Di samping itu, hama diberantas dengan pestisida nabati yakni kombinasi dari daun sirsat, daun paitan dan lavender, tembakau, kulit pohon kamboja, cabai, dan urine sapi. Sabit digunakan dalam pemanenan. Lalu, dilakukan pengumpulan malai padi yang rontok di atas terpal plastik, dan perontokan malai tersebut nantinya dilakukan dengan mesin perontok sehingga bulir padi dapat dihasilkan dan dilanjutkan dengan penggunaan mesin pembersih untuk pembersihan bulir padi tersebut. Pemasarannya dijalankan secara kolektif antara lain di Koperasi Agrika Karanganyar dan di pasar Mojogedang.

Kelompok tani ini dalam kegiatan operasionalnya belum mampu menerapkan sistem informasi manajemen yang optimal. Hal ini tampak dari proses kegiatan mencatat data hasil dari panen dan penjualannya. Laporan keuangannya pun masih tergolong sederhana. Oleh karena itu, untuk ke depannya di harapkan petani sudah mampu mengolah laporan keuanganya ataupun pencatatan segala administrasi dengan baik.

\section{Makna Keberadaan Mitra Bagi Lingkungan}

Kelompok Tani Rukun Makaryo merupakan wadah yang dapat menampung limbah sayuran, buah dan kotoran hewan, yang dapat diolah menjadi bahan pupuk organik. Didirikannya kelompok tani ini karena keinginan para petani untuk meningkatkan kesejahteraan hidupnya. Sejak tahun 1999, kelompok tani ini telah 
berkeinginan menciptakan pertanian organik dengan memperhitungkan bahwa pupuk dan pestisida annorganik tidak selalu bisa diandalkan para petani. Pupuk dan pestisida organik yang dipakai secara eksesif bisa memicu degradasi lahan pertanian, munculnya hama dan penyakit, dan rusaknya ekosistem. Dengan menilik situasi ini, maka kelompok tani ini setuju dengan kebijakan pemerintah yakni program "Go Organic 2010" yang ditujukan untuk menciptakan Indonesia sebagai negara yang memproduksi dan mengekspor pangan organik utama di dunia pada tahun 2010.

Permasalahan yang dihadapi oleh mitra di antaranya:

1. Kesulitan mendapatkan bahan baku yang digunakan untuk pembuatan POC yang berupa limbah sayuran, buah, dan kotoran ternak.

2. Peralatan yang digunakan untuk membuat pupuk organik masih sangat sederhana.

3. Produksi POC yang dihasilkan kurang mencukupi karena lahan pertanian sangat luas mengingat lahan pertanian di lingkungan mitra merupakan sentral pertanian organik di Kabupaten Karanganyar.

Tujuan dan manfaat dalam pengabdian yang telah dilakukan di antaranya:

1. Mengurangi pencemaran limbah khususnya limbah sayuran, buah dan kotoran hewan;

2. Menaikkan nilai tambah limbah sayuran, buah dan kotoran hewan yang bisa dimanfaatkan sebagai sumber mikroorganisme saat POC dibuat;

3. Menaikkan tingkat pengetahuan perihal pembuatan biofertilizer dan POC yang kualitasnya bagus;

4. Produksi POC yang bemutu sehingga kebutuhan pupuk pada lahan pertanian mitra bisa tercukupi.

\section{METODE}

Solusi yang ditawarkan sesuai dengan permasalahan mitra yaitu:

Tabel 1:

Diagram alir metode Penerapan Program Kemitraan Masyarakat Pembuatan POC Kelompok Tani Rukun Makaryo

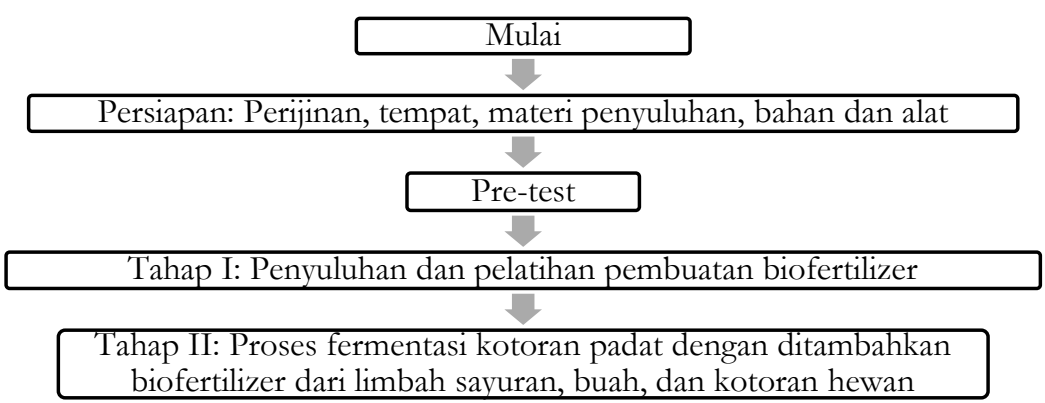

Post-test

Tahap III: Bantuan alat: alat pencampur bahan (mixing), silo, sekop, terpal, tempat naungan

Tahap IV: Pendampingan produksi pembuatan biostarter selama 14 hari

Pendampingan produksi pupuk organik cair selama 1 bulan

Evaluasi

Selesai 
Keterangan:

Tahap I. Pembuatan biostarter.

1. Persiapan mikroba:

Bahan-bahan mikroba dan media yang didapat dari penampungan limbah sayuran, buah dan kotoran hewan

2. Pembuatan biostarter.

Jika bahan mikroba ataupun media yang dipakai sudah dinyatakan siap, maka bahan-bahannya dikombinasi dengan perimbangan khusus, dan proses pemeraman selama dua pekan pun harus ditunggu dan harus diaduk setiap harinya, yakni pada waktu pagi dengan proses anaerob.

3. Pelaksana: Tim pengabdian Fakultas Pertanian Univet Bantara Sukoharjo (Ir. Catur Rini Sulistyaningsih, MM., Ir. Yos Wahyu H, M. Si., Ir Nugraheni R, MP., dan Yoesti Silviana A, SP., M.Sc.)

4. Partisipasi mitra: keikutsertaan sebagai penyedia sarana prasarana dan bahan.

Tahap II. Proses fermentasi kotoran padat dan sisa pakan ternak:

1. Mempersiapkan bahan yang akan difermentasi yaitu kotoran sapi, dolomit, dan sisa pakan, kemudian difermentasi secara semi aerob selama 1 bulan dengan menggunakn starter mikroba yang sudah diuji dilab.

2. Tujuan: memperoleh pupuk organik padat yang berkualitas yang siap diaplikasikan di lapangan.

3. Pelaksana: Tim Pengabdian Univet Bantara Sukoharjo (Koordinator Ir. Catur Rini Sulistyaningsih)

4. Partisipasi mitra: keikutsertaan sebagai peserta aktif
Tahap III. Analisis pupuk organik hasil dari fermentasi.

1. Melakukan pengujian baik secara mikro maupun makro apakah sesuai Standarisasi Pupuk Kompos No : 28/Permetan/SR.130/5/2009,22 Mei 2009, dan 2005.

2. Tujuan: mengetahui kandungan nutrisi pupuk,unsur hara yang terkandung dalam pupuk organik sudah sesuai dengan standar

3. Pelaksana: Tim Pengabdian Univet Bantara Sukoharjo (Koordinator Ir. Catur Rini Sulistyaningsih)

4. Pengamatan dan pelaksanaan dilaksanakan selama 1 bulan

5. Partisipasi mitra: keikutsertaan sebagai peserta aktif

\section{Rancangan Evaluasi terhadap Metode}

Penerapan Program Kemitraan

Masyarakat Pembuat Pupuk Organik Cair dengan "Kelompok Tani Rukun Makaryo"

Rancangan evaluasi terhadap peningkatan pengetahuan dan kemampuan peserta terhadap teori yang telah diberikan:

Evaluasi dilaksanakan sebanyak dua kali, yakni sebelum dimulainya program (pre test) dan sesudah dilaksanakannya (post test). Tiap-tiap jawaban diberikan skor dan disesuaikan dengan kriteria berikut: Skor $3=$ Sangat tahu/Sangat Bisa, skor $2=$ Tahu $/$ Bisa, skor $1=$ Tidak Tahu/Tidak Bisa. Nilai peserta program yaitu rerata skor seluruh jawaban. Nilai keseluruhannya yaitu nilai rerata semua partisipan. Evaluasi terhadap indikator keberhasilan program yaitu jika ditemukan skor post test mengalami peningkatan $\geq 25 \%$ dari pada skor pre test. 


\section{Rancangan evaluasi untuk bahan-bahan biostarter dan pupuk organik}

Tabel 2:

Tabel Rancangan Evaluasi untuk Bahan-Bahan Biostarter dan Pupuk Organik

\begin{tabular}{|c|c|c|c|c|}
\hline No & Nama & Introduksi Bahan & Evaluasi & Indikator Keberhasilan \\
\hline 1 & $\begin{array}{l}\text { Kelompok Tani } \\
\text { Rukun Makaryo }\end{array}$ & $\begin{array}{l}\text { - Rumen sapi } \\
\text { - Kecambah } \\
\text { - Bekatul } \\
\text { - Kunir } \\
\text { - Tetes tebu } \\
\text { - Empon-empon } \\
\text { - Kotoran ternak } \\
\text { sapi } \\
\text { - Sayuran } \\
\text { - Buah }\end{array}$ & $\begin{array}{l}\text { - Pengetahuan } \\
\text { bahan } \\
\text { - Langkah } \\
\text { pembuatan } \\
\text { biostrarter dan } \\
\text { pupuk organik } \\
\text { - Kapasitas } \\
\text { produksi }\end{array}$ & $\begin{array}{l}\text { - Peningkatan pengetahuan } \\
\text { terhadap bahan yang digunakan } \\
\text { untuk pembuatan biostarter } \pm \\
25 \% \\
\text { - Peningkatan prosedur } \\
\text { pembuatan pupuk organik } \\
\text { sebesar } 25 \% \text {. Perhitungan total } \\
\text { hasil pembuatan pupuk organic } \\
\text { dengan kebutuhan lahan }\end{array}$ \\
\hline
\end{tabular}

Bahan:

1. Kotoran hewan (kotoran kambing, sapi, ayam), limbah sayuran hijau, limbah buah busuk, batang pisang/ gedebog, sekam padi, dedak, jerami, dan sebagainya.

2. Gula merah/gula pasir

3. Bioaktivator (EM4) *optional

4. Air bersih seperlunya

5. Ember yang memiliki penutup/ tong plastik kedap udara. Persiapkan selang. Penutup tong yang ukurannya sama dengan lubang selang juga harus dilubangi.

Langkah-langkah pembuatan POC:

1. Lakukan pemotongan atau cincang bahan, contohnya sayuran, pisang, batang, dan daun-daun, lalu dicampur dengan bahan organik lain, contohnya feses hewan.

2. Masukkan bahan tersebut ke dalam tong, dan air pun bisa ditambahkan. Takaran yang dianjurkan yaitu 2 bagian bahan organik $=1$ bagian air bersih. Lakukan pengadukan sampai semuanya bercampur dan merata. Masukkan bahan organik yang sudah tercampur ke dalam wadah dan lakukan pengadukan lagi sampai rata.

3. Larutkan gula merah sebanyak 5 liter air dengan bioaktivator EM4. Lakukan pengadukan sampai rata. Laurutan ini kemudian dimasukkan ke dalam tong atau ember yang sudah diisi bahan baku organik.

4. Tutupi tong dengan plastik hingga rapat sehingga udara tidak bisa memasukinya. Setelah sepekan, buka tutup tong sedikit saja. Hal ini ditujukan agar suhu bisa stabil dan gas yang diproduksi akhirnya terbuang.

5. Buka penutupnya setelah 30 hari. Hal ini ditujukan agar tingkat kematangannya bisa dicek. Jika aroma yang muncul serupa dengan aroma tape, berarti adonan bisa dipergunakan.

6. Saring ampas adonan dengan memakai saringan. Cairan yang sudah terpisah dari ampas siap dipakai. Ampasnya pun dapat dipakai sebagai media tanam organik atau pupuk organik padat.

7. Aplikasikan: 1 liter POC yang ditambah dengan 2 liter air; lakukan penyiraman pada tanaman yang hendak dipupuk.

\section{HASIL DAN PEMBAHASAN}

Kegiatan awal yang dijalankan yaitu melakukan koordinasi dengan ketua kelompok Tani Rukun Makaryo, dan perwakilannya kelompok tani. Rapat Koordinasi berjalan selama lebih kurang 30 menit. Hasil rapatnya yaitu pembahasan 
perihal persiapan pelaksanaan untuk pembuatan biofertilizer yang dilanjutkan untuk pembuatan POC. Bahan-bahan yang dipakai akan disediakan oleh Tim Pengabdi Univet Bantara Sukoharjo. Peserta yang akan diundang dalam pelatihan nanti direncanakan lebih kurang 15 orang petani, yang terlibat dalam pertanian organik lingkup Kec. Mojogedang dan sekitarnya. Rapat Koordinasi berjalan lancar dan selanjutnya telah ditentukan hari dan tanggal pelaksanaan Pelatihan Pembuatan Biofetilizer dan pupuk organik.

Tahap pelaksanaan sudah diselesaikan Tim pengabdian sesuai dengan metodenya. Tahap yang sudah dilaksanakan di antaranya:

\section{Tahap I: Pembuatan Biofertilizer}

Persiapan mikroba: bahan mikroba dan media yang diaplikasikan di antaranya rummino bacillus, saccharomyces cerevisiae, azotobacter, tetes tebu, dan media protein. Partisipan Kegiatan Pelatihan Pembuatan Biofertilizer meliputi pengurus dan anggota kelompok tani Rukun Makaryo, termasuk representatif kelompok tani lainnya di area Kec. Mojogedang. Hasil yang didapatkan yaitu MOL dapat diternakkan dan difungsikan sebagai "starter" untuk membuat kompos, pupuk cair, termasuk pakan ternak.

Ditambahkannya MOL ke dalam konsentrat ternak andil peran dalam proses fermentasi ketika bahan makanan basal dicerna (pencernaan fermentatif) di mana hal ini menaikkan tingkat kualitas daging. Saat membuat starter MOL, langkah awalnya yaitu persiapkan mikrobia lkal, misalnya induk bateri, JLK2 (jahe, laos, kunir, dan kencur), stimulator akar, nutrisi, buah, dsb. Lakukan penyaringan selama 10-15 hari, dan ampas yang dihasilkan bisa dicampur dengan pupuk organik padat. Indukan bakteri adalah starter MOL, dan pemanfaatannya disesuaikan dengan kebutuhannya (Sulistyaningsih, 2012). Warna starter yang sudah dibuat yaitu coklat dan aromanya pun tidak menyengat. Lalu, tutupi starter MOL tersebut dalam gentong (silo) yang nantinya bisa dipakai sebagai indukan bakteri ketika pupuk organik dibuat.

Hasil biostarter bisa diaplikasikan sebagai bahan starter sebab hasil analisis total pertumbuhan mikrobia masih mempunyai kesesuaian dengan standarnya. Ketua dan anggota tim pengabdi, termasuk 4 orang mahasiswa yang mengasisteninya menghadiri Tahap I, sementara 14 anggota Rukun Makaryo menghadiri Keikutsertaan sebagai penyedia sarana prasarana dan bahan.

\section{Tahap II: Proses Fermentasi Kotoran menjadi Pupuk Organik Cair}

Tujuan yang ingin dicapai yaitu untuk mendapatkan POC yang berkualitas yang siap diaplikasikan di lapangan. Peserta pelatihan pembuatan POC meliputi pengurus dan anggota kelompok tani Rukun Makaryo, termasuk warga Desa Pereng, Mojogedang yang memiliki lahan Pertanian Organik dan dihadiri kelompok tani Rukun Makaryo dan tim pengabdi. Bahan-bahan POC di antaranya: (1) kotoran ternak 1 ton, (2) katul $20 \mathrm{~kg}$, (3) sekam padi/brambut 10 karung, (4) Induk bakteri/starter 2 liter, (5)Tetes tebu / mollase 2 liter, (6) JLK2 yang didominasi limbah sayuran, buah dan kotoran hewan sebanyak 2 liter.

Fungsi dari tetes tebu ini yaitu sebagai pelengkap nutrisi bagi mikroba yang akhirnya proses fermentasi bisa dipercepat dan kandungan $\mathrm{N}$ dalam pupuk pun dapat ditingkatkan. Cara pembuatannya yaitu kotoran ternak/sapi, sekam, dan bekatul diaduk-aduk sampai merata. Induk bakteri, mollase, JLK2 yang didominasi limbah sayuran, buah dan kotoran hewan dikocorkan dan ditambah air secukupnya supaya merata, timbun. Setiap minggu dilakukan pembalikan dan penyiraman cukup basah, setelah 1 bulan pupuk sudah jadi. Pupuk organik hasil dari penambahan biofertilizer limbah sayuran, buah dan kotoran hewan kelompok tani Rukun Makaryo bersifat dingin, remah, wujud 
aslinya tidak nampak, baunya tidak menyegat sesuai dengan standar kriteria pupuk yang telah jadi.

Rancangan Evaluasi terhadap Penerapan Ipteks Pembuatan Pupuk Organik Cair dengan Mitra "Kelompok Tani Rukun Makaryo"

Sebelum dimulainya kegiatan, anggota kelompok Rukun Makaryo diharuskan menjalani pre test. Usai penyuluhan, peserta dites untuk menyelesaikan soal post test.

Tabel 2:

Penilaian Pre-test dan Post-test

\begin{tabular}{|l|l|l|l|l|l|}
\hline No & Nama & $\begin{array}{c}\text { Nilai } \\
\text { Pre- } \\
\text { test }\end{array}$ & $\begin{array}{c}\text { Nilai } \\
\text { Post- } \\
\text { test }\end{array}$ & $\begin{array}{c}\text { Pening- } \\
\text { katan } \\
\mathbf{( \% )}\end{array}$ & Skor \\
\hline 1 & Baskoro & 50 & 80 & 37.50 & 2 \\
\hline 2 & Endang & 40 & 80 & 50.00 & 2 \\
\hline 3 & Mamet & 50 & 80 & 37.50 & 2 \\
\hline 4 & Suro & 50 & 80 & 37.50 & 2 \\
\hline 5 & Yatno & 40 & 80 & 50.00 & 2 \\
\hline 6 & Tomo & 50 & 80 & 37.50 & 2 \\
\hline 7 & Suto & 50 & 80 & 37.50 & 2 \\
\hline 8 & Sular & 40 & 80 & 50.00 & 2 \\
\hline 9 & Sulis & 50 & 80 & 37.50 & 2 \\
\hline 10 & Warsi & 40 & 60 & 33.33 & 2 \\
\hline 11 & Tarti & 40 & 70 & 42.86 & 2 \\
\hline 12 & Warni & 40 & 70 & 42.86 & 2 \\
\hline 13 & Sutar & 30 & 80 & 62.50 & 2 \\
\hline 14 & Toni & 40 & 70 & 42.86 & 2 \\
\hline 15 & Asih & 50 & 80 & 37.50 & 2 \\
\hline Rata-rata & 44 & 76.67 & 42.46 & \\
\hline
\end{tabular}

Keterangan: Skor 3 = Sangat tahu/Sangat Bisa, skor $2=$ Tahu $/$ Bisa, skor $1=$ Tidak Tahu $/$ Tidak Bisa.

Tabel 1 mengindikasikan penilaian pengetahuan perihal penyuluhan dan pelatihan pemanfaatan limbah sayuran, buah dan kotoran hewan sebagai bahan pembuatan POC di Kelompok Tani Rukun Makaryo. Evaluasi indikator keberhasilan mengindikasikan skor post test meningkat $\geq$ $25 \%$ dari pada skor pre test. Data menunjukkan, 15 partisipan yang menjalani kedua tes tidak mendapat nilai yang di bawah 25\%. Kesimpulannya, indikator keberhasilan yang sudah dicapai dalam kegiatan ini sudah 100\% dan anggotanya yang mendapat skor 2 dan 3 berjumlah 15 orang, serta rerata peningkatannya sebanyak $42,46 \%$.

\section{KESIMPULAN}

Hasil kegiatan pengabdian kepada masyarakat dilakukan dan evaluasi indikator keberhasilan penyuluhan dan pelatihan mengindikasikan skor post test meningkat $\geq$ $25 \%$ dari pada skor pre test. Dari 15 orang peserta yang menjalani kedua tes, tidak ada yang mendapat nilai pengingkatan pemahaman di bawah 25\%. Pendek kata, indikator keberhasilan yang sudah dicapai dalam kegiatan ini sudah 100\% dan anggotanya yang mendapat skor 2 dan 3 berjumlah 15 orang, serta rerata peningkatannya sebanyak $42.46 \%$.

\section{DAFTAR PUSTAKA}

Catur, R., Catur B. (2013). IbM CV.Agrobiz. Abadi Jaya Di Gondangrejo, Karanganyar. Laporan Ipteks Bagi Masyarakat. Univet Bantara Sukoharjo

Catur, R., Catur B. (2014). Produksi Pupuk Organik Anaerob Dengan Penambahan Biofertilizer Dan Uji Kompatibilitas Bibit Tanaman Pangan dan Holtikultura. Laporan Penelitian Hibah Bersaing. Univet Bantara Sukoharjo

Catur R., Nugraheni, Sri H. (2016). Penentuan Pemakaian Dosis dan Macam Biofertilizer Dalam Pembuatan Pupuk Organik Padat Terhadap Kandungan Unsur Makro dan Mikro Nutrien Serta Logam Berat. Laporan Akhir Penelitian Hibah Bersaing. Univet Bantara Sukoharjo

Damayanti, V. Et al. (2017). Pengaruh Penambahan Limbah Sayuran terhadap Kandungan C-organik dan Nitrogen Total dalam Vermikomposting Limbah Rumen dari Sapi Rumah Potong Hewan (rph). http://ejournals1.undip.ac.id/index.php/tlingkungan Jurnal Teknik Lingkungan, 6(1)

Farida E. (2000). Pengarub Penggunaan Feses Sapi dan Campuran Limbah Organik Lain Sebagai Pakan atau Media Produksi Kokon dan Biomassa Cacing Tanah Eisenia foetida 
savigry. Skripsi Jurusan Ilmu Nutrisi dan Makanan Ternak. IPB, Bogor.

Henry K. Indranada. (1986). Pengelolaan Kesuburan Tanah. Bina Aksara. Semarang

Jalaluddin, Nasrul ZA, Rizki Syafrina, (2016), Pengolahan Sampah Organik Buah-buahan menjadi Pupuk dengan Menggunakan Effective Microorganism, Aceh: Jurnal Teknologi KimiaUnimal.

Musnamar (2006). Manfaat Pupuk Cair Organik. http://tha.co.id/berita-3manfaat -pupuk-cair-organik.html. Diakses pada tanggal 9 September 2018.

Nisa, Khalimatu Dkk. (2016). Memproduksi Kompos dan Mikro Organisme Lokal. Jakarta: Bibit Publisher.

Nur, M. (2019). Analisis Potensi Limbah Buah-Buahan sebagai Pupuk Organik Cair. Departemen Teknik Mesin dan Industri FT UGM. ISBN 978-62392050-0-3. Pp. ER28-ER32

Rinsema. (1986). Pupuk dan Pemupukan. Bharata Karya Aksara. Jakarta

Sudarmi, Nugraheni, Catur R., Yos W. (2010). Iptek Bagi Masyarakat Kelompok tani Pembuatan Pupuk Organik dari Limbah Jerami di Kelurahan Begajah $\mathrm{Kec} / \mathrm{Kab}$ Sukobarjo. Laporan Pengabdian kepada Masyarakat. Univet Bantara Sukoharjo

Sihombing. (2000). Teknik Pengelolaan Limbah Kegiatan/Usaha Peternakan.Pusat Penelitian Lingkungan Hidup Lembaga Penelitian. Institut Pertanian Bogor. Bogor.

Soehadji. (1992). Kebijaksanaan Pemerintah dalam Pengembangan Industri Peternakan dan Penangan Limbah Peternakan. Direktorat Jenderal Peternakan Departemen Pertanian.Jakarta.

Tang, P. Y., C, J. Wong., K, K. Woo. (2011). Optimization of Pectin Extraction from Peel of Dragon Fruit (Hylocereuspolyrhizus). Asian Jurnal of Biological Sciences, 4(2): 189-195. 